\title{
Internet of Things at the Service of
}

\section{Bioconstruction}

Fabián-Ricardo Corredor-Sánchez; Juan-Sebastián González-

Sanabria; Miguel-Ángel Mendoza-Moreno

Citation: F.-R. Corredor-Sánchez, J.-S. González-Sanabria, M.-Á.

Mendoza-Moreno, "Internet of Things at the Service of

Bioconstruction," Revista Facultad de Ingeniería, vol. 30 (55), e12266,

2021. https://doi.org/10.19053/01211129.v30.n55.2021.12266

Received: November 17, 2020; Accepted: December 22, 2020;

Published: January 01, 2021

Copyright: This is an open access article distributed under license $\underline{\mathrm{CC}}$

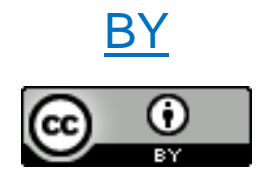

Conflict of interest: The authors state there is no conflict of interest. 


\title{
Internet of Things at the Service of Bioconstruction
}

\author{
Fabián-Ricardo Corredor-Sánchez ${ }^{1}$ \\ Juan-Sebastián González-Sanabria² \\ Miguel-Ángel Mendoza-Moreno³
}

\begin{abstract}
The Internet of Things (Internet of Things - loT) approach promotes the interconnection of objects that humans use on a daily basis so that they are administered, controlled and/or monitored through telematic technologies. This paradigm has a wide field of application to support several development schemes in a variety of areas. In the case of construction, there are home automation schemes, but regarding bio-constructions, the myth of incompatibility between digitized systems and "bio" schemes exists. However, bio-constructions require aesthetic, structural, environmental and technological considerations to integrate efficient and friendly systems, contributing to a sustainable environment, generating and regulating the resources of the environment in which they are implemented. In this way, a documentary research process has been developed to determine the degree of applicability of loT for green buildings. As a result, a set of IoT technologies was identified, which can promote the administration and control of the normatively established agents involved in a bio-construction for living spaces.
\end{abstract}

Keywords: Baubiologie; bioconstruction; biohouses; loT; Internet of things.

\footnotetext{
${ }_{1}^{1}$ M. Sc. (c) Universidad Pedagógica y Tecnológica de Colombia (Tunja-Boyacá, Colombia).

2 M. Sc. Universidad Pedagógica y Tecnológica de Colombia (Tunja-Boyacá, Colombia). juansebastian.gonzalez@uptc.edu.co. ORCID: 0000-0002-1024-6077

3 Ph. D. Universidad Pedagógica y Tecnológica de Colombia (Tunja-Boyacá, Colombia). miguel.mendoza@uptc.edu.co. ORCID: 0000-0001-9000-5881
}

Revista Facultad de Ingeniería (Rev. Fac. Ing.) Vol. 30 (55), e12266. January-March 2021. Tunja-Boyacá, 


\section{Internet de las cosas al servicio de la bioconstrucción}

\section{Resumen}

El enfoque de Internet de las Cosas (Internet of Things - loT) promueve la interconexión de los objetos que el ser humano usa cotidianamente para que sean administrados, controlados y/o monitoreados a través de tecnologías telemáticas. Este paradigma tiene un amplio campo de aplicación, como apoyo a diferentes esquemas de desarrollo en diversidad de áreas. Para el caso de las construcciones, se cuenta con esquemas domóticos, pero existe el mito en este ámbito de la incompatibilidad entre los sistemas digitalizados y los esquemas "bio". Sin embargo, las bioconstrucciones requieren consideraciones estéticas, estructurales, ambientales y tecnológicas para integrar sistemas eficientes y amigables, contribuyendo a un medio ambiente sostenible, generando y regulando los recursos del entorno en el que son implementadas. De esta manera, se ha desarrollado un proceso de investigación documental guiado a determinar el grado de aplicabilidad del loT para bioconstrucciones. Como resultado, se identifica un conjunto de tecnologías propias del loT que pueden promover la administración y control de los agentes establecidos normativamente para una bioconstrucción de espacios habitacionales.

Palabras clave: Baubiologie; biocasas; bioconstrucción; Internet de las Cosas.

\section{Internet das coisas a serviço do edifício verde}

\section{Resumo}

A abordagem da Internet das Coisas (IoT) promove a interconexão de objetos que os seres humanos usam diariamente para que sejam gerenciados, controlados e / ou monitorados por meio de tecnologias telemáticas. Este paradigma tem um amplo campo de aplicação, como suporte para diferentes esquemas de desenvolvimento em diversas áreas. No caso das construções, existem esquemas de automação residencial, mas existe um mito nesta área da incompatibilidade entre sistemas digitalizados e esquemas "bio". No entanto, as bioconstruções requerem considerações estéticas, estruturais, ambientais e tecnológicas para integrar sistemas eficientes e amigáveis, contribuindo para um ambiente 
sustentável, gerando e regulando os recursos do meio em que são implementadas. Dessa forma, um processo de pesquisa documental foi desenvolvido para determinar o grau de aplicabilidade da loT para edifícios verdes. Como resultado, identifica-se um conjunto de tecnologias loT que podem promover a administração e o controle dos agentes instituídos pela regulamentação para uma bioconstrução de espaços residenciais.

Palavras-chave: Baubiologie; biohouses; bioconstrução; Internet das Coisas. 


\section{INTRODUCTION}

The implementation of sustainable components in the different areas of knowledge of humans is a fundamental factor for the preservation of the mean [1], reason for which the introduction of Internet of Things (IOT) in the design of bioconstructions is an opportunity to support this field technologically. The proposal of an application framework, where loT artifacts and structures support the components that characterize the design and normativity of bioconstructions -mainly housesconstitutes a technological innovation instrument applied to environmental and architectonic fields.

Bioconstructions have a technical norm of measurement in Baubiologie, from the year 2015 [2], to measure indicators in three areas: i) fields, waves and radiation; ii) domestic toxins, pollutant agents and interior environment, and iii) fungus, bacteria and allergens [2]. These indicators open up the possibility for loT components to supply the monitoring and controlling functions. Besides, bioconstructions require resource exploitation characteristics, such as energy and drinking water, for which loT can promote processes adjusted to rationalization and personalization of consumption, this can be seen as an input in sustainability.

Some aspects of loT promote the efficiency of energetic resources, providing energy conservation, cost reduction and healthy living environments [3]; this way, the exploitation of basic consumption resources for humans can be accomplished in an habitational construction.

The use of loT devices is so high that, for the year 2020, a connection was estimated of between 25 and 50 billion devices in the world [4]. It must be clarified that in this projection, additional to devices such as smartphones, computers and tablets, artifacts such as the ones used in big railway projects [5] as well as basic household appliances were included. However, other researchers precise a number of 28 billion smart devices connected around the world in 2021, considering the scene of the $5 \mathrm{G}$ networks [6]. This growth forecast includes an equivalent increase in the technological market, which offers services for the use and transformation of traditional elements into smart devices. 
Figure 1 shows the periods in which the world economy has suffered radical transformations, highlighting that the fourth industrial revolution is being promoted by loT, given the massive automatization of processes.

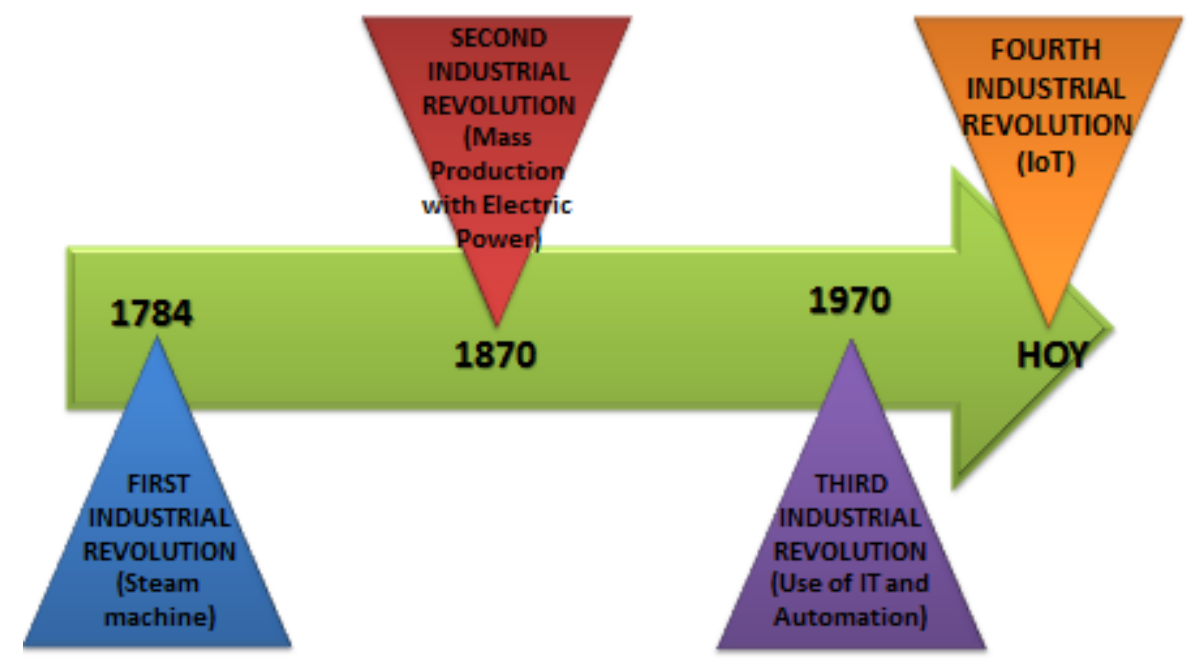

Fig. 1. Adaptation of the four industrial revolutions.

An element becomes a smart device when it has three main characteristics: contextual conscience, autonomy, and connectivity [4]. The contextual conscience is obtained through the use of sensors and the interaction with other elements; the autonomy is obtained through computational instructions that frame the functional acting of the element, and the connectivity is accomplished through the transmission of interoperating information. However, nowadays, the elements that reach the smart device characteristic inside the loT structure have problems related to energy consumption and integration with heterogeneous devices.

In the aim to give an adequate scenario for the integration of loT for the support of bioconstructions, the present paper is structured as follows: a section where the measurement agents are conceptualized for a house-type bioconstruction, along with usable resources; a section where the loT approach is presented, characterizing the artifacts and structures that promote it, followed by a section that shows the components proper of loT that allow the display of house-type bioconstructions. Finally, there is a section that describes the developments to be considered as future work for the complement of loT in the promotion of bioconstructions.

Revista Facultad de Ingeniería (Rev. Fac. Ing.) Vol. 30 (55), e12266. January-March 2021. Tunja-Boyacá, 


\section{Methodology}

The development of the research has a mix approach, giving quantitative factors in the measurement, analysis and deduction of the results of natural and energetic resources, inside and outside of a living space. Qualitative factors are also included in the characterization of the IoT elements that support biohouse principles.

The process begins with the review of specialized scientific literature with the help of digital databases on topics related with engineering, technology, architecture and environment. Here, the current classifications (conceptual and normative) of bioconstructions are highlighted, which are given by international competent organizations. The main used databases were Scopus and IEEE, in which the following search terms were used: "Bioconstruction", "Baubiologie", "bioconstruction+loT", "bioconstruction+Internet of Things" y "Baubiologie+loT". Additionally, the patterns and materials of this kind of constructions offered by recognized specialized journals are studied. Likewise, the evolution that loT has had in the last ten years, in LAN networks and in the support of energy sources and implementations in housing constructions, is studied.

The final result gives the possibility of performing a methodologic synthesis that includes the formulation of IoT architecture and artifacts that work as support in each of the requirements of a biohouse, with operability results and measurable consumption registers, as well as resource optimization. These will be the base of the analysis of the consistency of applying loT in the development of bioconstructions.

\section{Contextualizing Bioconstructions}

The living quality through the use of ecological materials, the decrease of toxic agents in construction and the resource management, among others, are advantages in the development of a bioconstruction. Surely, this type of house can have the same benefits of a conventional one, with the difference of a visibly 
smaller environmental impact, reduction of the maintenance time, energy saving and cost decrease [7].

The guideline in the field of bioconstructions is the document developed by Maes \& Institut für Baubiologie + Ökologie (2008), where this type of construction is standardized through the IBN SBM-2008 norm, which years later was adjusted and is nowadays constituted as the IBN SBM-2015 norm [2]. However, this standard rules all kinds of edifications framed in the Baubiologie, but does not yet count with specifications for other types of construction [8]. Based on this norm, we elevate the concept of bioconstruction to a deeper field. But not only must factors stablished in the norm be considered, also, the ones introduced by expert researchers, which contribute to this investigation with arguments, practices, and construction patterns of environmental and sustainable type; these can be a solution to pollution topics [9].

The principle of the technical measurement norm in Baubiologie pursues the detection and reduction of physical, chemical, and biological risks in inhabited spaces, in search of living environments with the lowest pollution and highest naturality possible [8]. The measurements and the display of indicators of these risks are divided in three associated distribution frames, according to the la IBN SBM-2015 norm, and are shown in Figure 2.

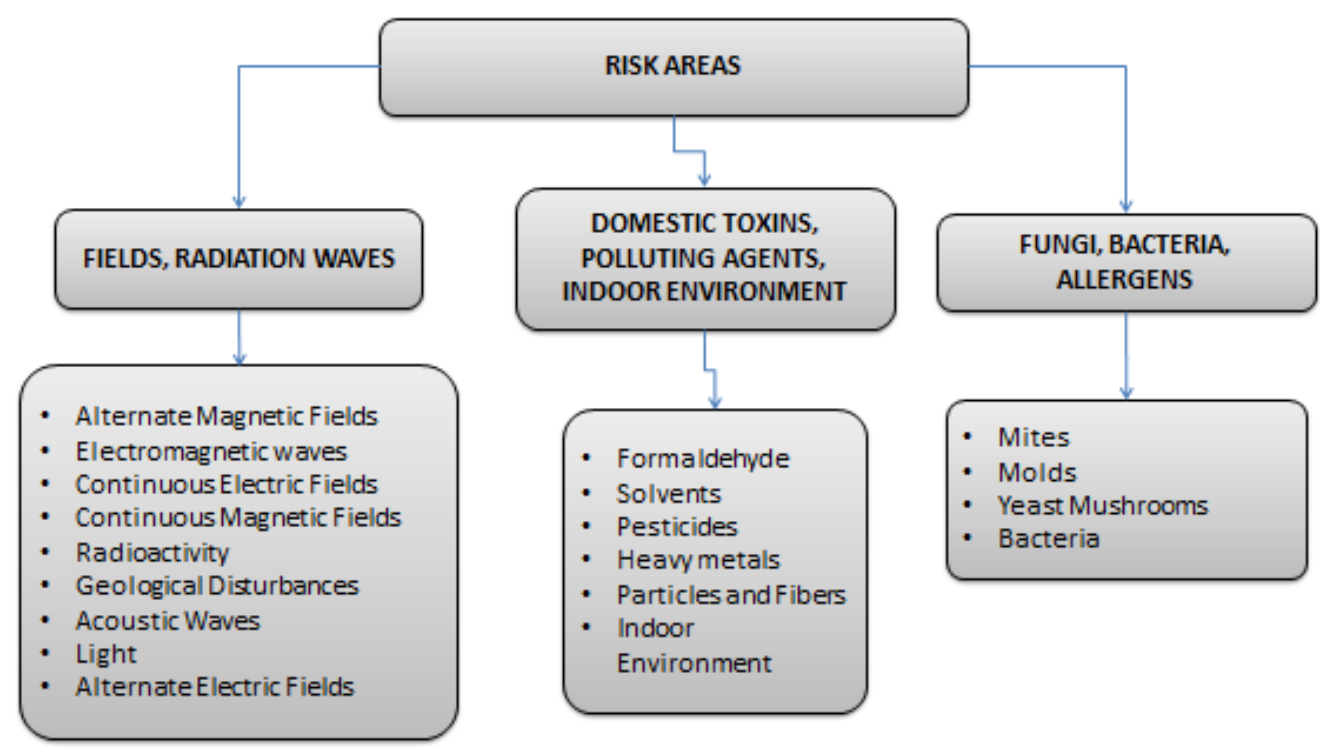

Fig. 2. Risk areas according to the measurement technical norm in Baubiologie. 
From the associated risks above, IBN presents the complement of the IBN SMB2015 norm, in which the rubrics that measure the indicators for the three areas of the norm are portrayed, as seen in Table 1 [10]. The resulting values have a descriptive frame presented by the standard - measure units and instruments - in which an analysis must be done for the references of each area, in order to extend and deepen the measurement evaluations of the risks in Baubiologie [11].

Table 1. Adaptation of the rubrics for the indicative values of measurement in Baubiologie [10].

\begin{tabular}{|c|c|c|c|c|}
\hline \multirow[b]{2}{*}{ Area } & \multicolumn{4}{|c|}{ Measurement Rubrics } \\
\hline & Non-Significative & $\begin{array}{c}\text { Slightly } \\
\text { Significative }\end{array}$ & $\begin{array}{c}\text { Strongly } \\
\text { Significative }\end{array}$ & $\begin{array}{c}\text { Extremely } \\
\text { Significative }\end{array}$ \\
\hline $\begin{array}{c}\text { Fields, Waves, } \\
\text { Radiation }\end{array}$ & \multirow{3}{*}{$\begin{array}{l}\text { Precautions must be } \\
\text { held; however, the } \\
\text { indicators' values } \\
\text { are "normal". This } \\
\text { means they are } \\
\text { found in the } \\
\text { environment of the } \\
\text { house frequently } \\
\text { and/or almost } \\
\text { inevitably. }\end{array}$} & \multirow{3}{*}{$\begin{array}{l}\text { Improvements must } \\
\text { be done whenever } \\
\text { it is possible, as a } \\
\text { precaution for some } \\
\text { people's sensibility, } \\
\text { in consequence } \\
\text { with certain } \\
\text { resulting values } \\
\text { measured in the } \\
\text { house. }\end{array}$} & \multirow{3}{*}{$\begin{array}{c}\text { The } \\
\text { corresponding } \\
\text { improvement } \\
\text { must not take } \\
\text { long, as a } \\
\text { precaution for } \\
\text { indicators that } \\
\text { bring biological } \\
\text { and sanitary } \\
\text { consequences } \\
\text { to the house. }\end{array}$} & \multirow{3}{*}{$\begin{array}{c}\text { The application of } \\
\text { the correction must } \\
\text { be immediate as a } \\
\text { response to the alert } \\
\text { generated by the } \\
\text { high values of the } \\
\text { indicators found in } \\
\text { the house. }\end{array}$} \\
\hline $\begin{array}{l}\text { Domestic toxins, } \\
\text { Pollutant Agents, } \\
\text { Interior Ambience }\end{array}$ & & & & \\
\hline $\begin{array}{c}\text { Fungus, Bacteria, } \\
\text { Allergens }\end{array}$ & & & & \\
\hline
\end{tabular}

Additionally, there are lineaments of bioconstructions that determine the environmental impact they provoke in their lifecycle: During the construction During the useful life - After the useful life; and are defined in terms of impact, energy, consumption and waste. These terms are framed in a common process that is the selection and use of the materials that are part of the construction [12]. In Figure 3, the main factors that influence technically and economically in the environmental impact generated by a construction can be seen; this has stimulated the development of solutions to improve the efficiency of the consumption of resources like water [13], energy [14] and food supply in controlled environments [15]. 


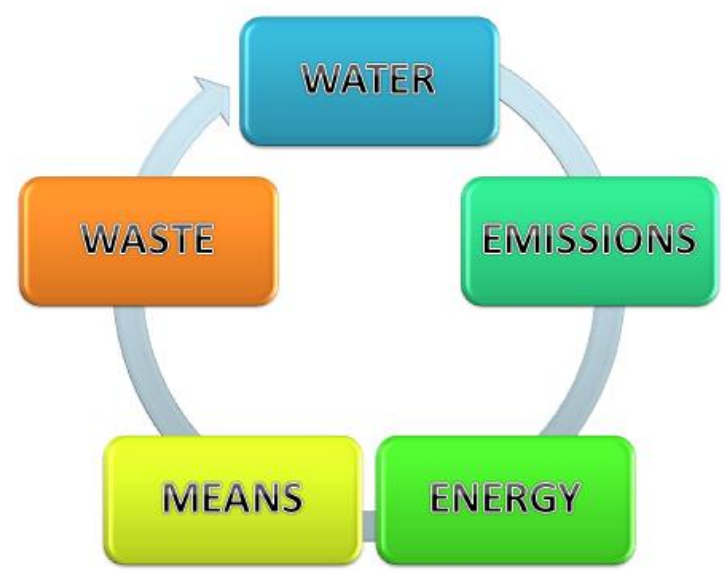

Fig. 3. Higher influence factors in the reduction of the environmental impact of a bioconstruction.

From these factors, the term of Sustainable Construction is conceptualized, its product will be subject of measurement through the IBN SMB-2015 technical norm. However, there are evaluation criteria applied to the construction process from the beginning to the end of its lifecycle [12]:

$\checkmark$ Geobiological and Environmental Quality Assessment and Control

$\checkmark$ Products, Materials and Installation Systems Assessment and Control

$\checkmark$ Care and Control of the Transformation Activity Quality and Requalification of the built environment

$\checkmark$ Contention in the use of non-renewable energetic resources and reduction of polluting emissions

$\checkmark$ Minimization of the environmental impact during the Production, Management, and Recuperation/Disposal of the construction components phases

Finally, the development process of a bioconstruction is consolidated with the parameters that define the concrete actions that must be carried out for the management of a sustainable construction [12]:

$>$ Correct integration with the physical environment

Adequate selection of materials and processes

$>$ Efficient management of water and energy

$>$ Planification and control of the waste generation

Creation of a healthy interior 


\section{Quality-price efficiency}

\section{A. Action Lines in the loT Paradigm}

The Internet of Things (loT) promotes the interconnection of objects that humans use every day, through a smart infrastructure. In the same way, these objects become smart devices for the service, management and control of humans. In Figure 4, the current tendencies of IoT applications are observed, they give key factors such as the transference rates according to requirements, and the implication levels of applications, for both the machine and the human.

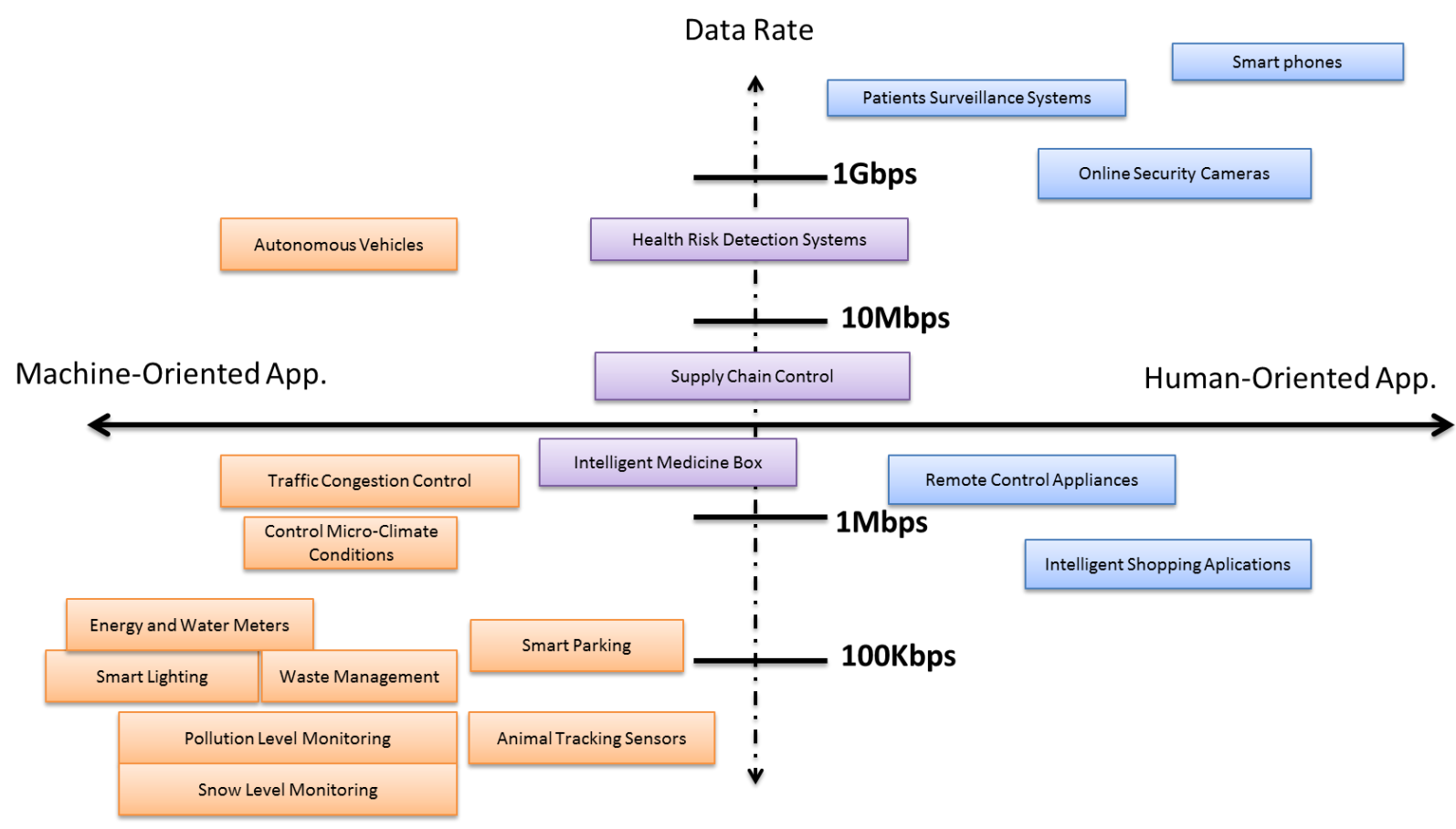

Fig. 4. Adaptation of the IoT applications Classification [16].

In loT, certain areas have been highlighted where the interest for generating higher approximations is collected, at the same time that their improvement will potentiate new developments (Figure 5). Said areas correspond to the consumption of energy, transference rates, security and interoperability. Likewise, it is proposed to attack the problem of the energetic consumption of devices through the specific configuration of sensor nodes, in order to decrease the data transmission 
packages, which represents a time-energy saving [17]. This without leaving aside the reliability of data that is controlled through the redundancy of sensors implemented in the same configuration. Also, there are parallel technologies that add up to the loT evolution, like the Wireless Reversible Paradigm (TR), which makes the most of the environment energy, optimizing the consumption of smart devices; provides security in the physic layer of the loT model; allows integration of heterogeneous devices, and is, visibly, a promising 5G technology [18].

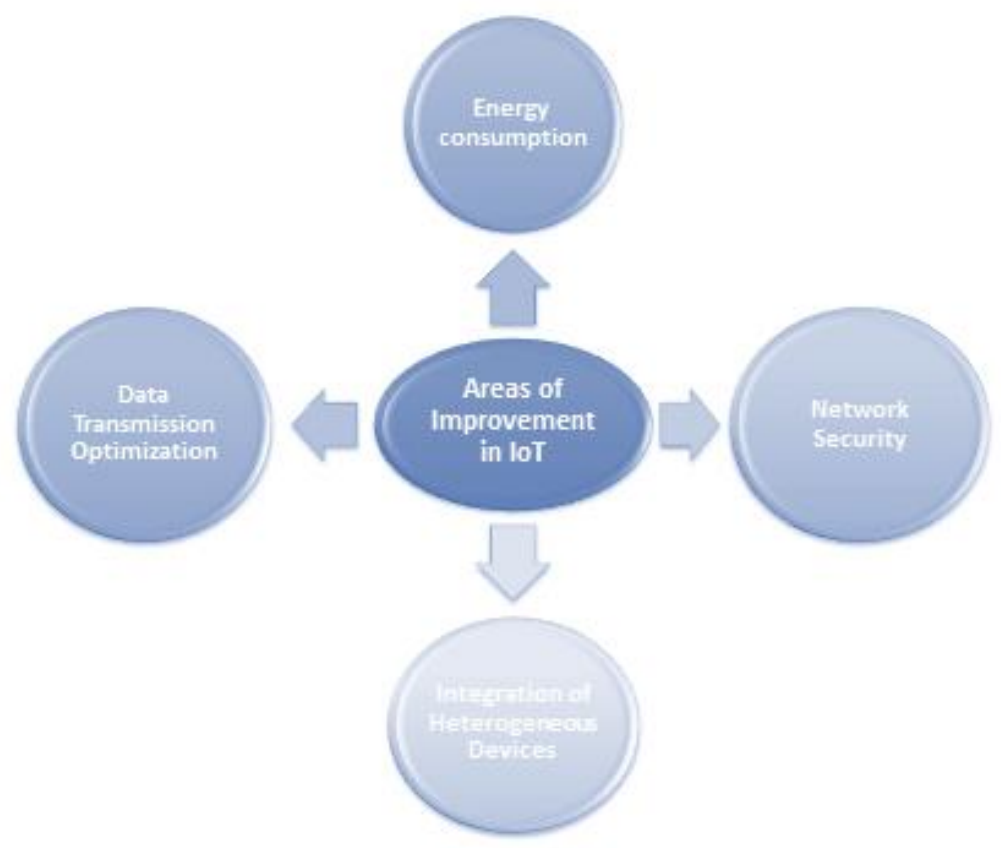

Fig. 5. Improvement areas for the loT architecture.

On the other hand, there is research focused on the loT network security [19], where algorithms are proposed for the management of security, as well as constant monitoring of the physical parameters, and an upgrade for the model medium access control layer, as an strategy for energetic consumption reduction, based on the IEEE 802.15.4 standard. This standard, that defines the physical level and medium access control in WPAN networks, is also the base on which the set of high-level protocols of wireless Zigbee communication is set. An important study has been made through it, whose object is based on the adaptation of heterogeneous devices that are controlled via infrared, getting stable governance 
and device independence as a result, with the disclaimer of making possible the escalation to higher coverage networks [20].

In this sense, it is observed that the interoperability of smart devices in IoT implementations is a primordial factor, since manufacturers must overcome the development of homogeneous ecosystems that oppose to the implementation dynamics. However, this is not easy to achieve, since not all manufacturers fulfill the same needs and requirements in the implementation devices [21]-[22]. Thus, it is proposed to appeal to the logic of information exchange between applications through a Middleware, as a strategy for the integration of heterogeneous devices.

Since the variable of the smart device users grows every day, the theorical decision models must be optimized and evolve, since they are the opening for the design and implementation of a good loT architecture [23], supporting the articulation of objects and giving place to platforms that allow harmony in the decision making. These platforms exist, however, they depend on the device manufacturers, for which the problem of interoperability and integration returns. For the above, the decision making in loT must be better supported by the following fundamental objectives [24]: intelligent knowledge and energetic efficiency as services, boosting the application of an integrated management system that connects loT devices. Likewise, a support based on an operating system is required, so that the devices are not managed in an individual way, therefore, a smart model based on TensorFlow is proposed.

Nowadays, it can be said that the needs of any loT application aim for high transmission speed, bandwidth, low latency, high performance, and a successful interoperability; and, just as described by Shafique, Khawaja, Sabir, Qazi, \& Mustaqim (2020), the main objective of loT is to provide operation ease, remote control, and configuration for the final user. This way, a scenario of how 5G technology becomes a "trampoline" for loT can be seen, allowing the use of several new technologies that enable the display of architectures in which many of the drawbacks for loT before $5 \mathrm{G}$ are neutralized [25]. 


\section{B. Integrating Bioconstructions with loT}

As it has been shown, loT has proposed models for its applicability in different environments and scenarios, however, given that this research is focused on its application on bioconstructions, only the models that have a house-type construction reach are examined, which requires a very high resource optimization in the infrastructure level.

The loT paradigm has developed control and administration technologies for small networks, through the use of sensors and actuators [26], in order to obtain practical and successful results, ideal for house-like environments. In the same way, it has been developed in residential coverage, with successful and scalable results for the control of home electric elements [27].

Analyzing the research from the last three years, where important developments essentially on data speed, energetic efficiency, and scalability improvement have been proposed [28], it can be identified that several of these technologies can be precisely applied to micro perception measurements on toxins and pollutant agents, sensorial wave measurements, and fungi, bacteria and allergens detection. These are the three main identified elements to be controlled in a bioconstruction. It must be highlighted that, even though loT has dabbled in the display of houses, we could not find a particular interest for these applications to be relevant in the control of elements that are unnoticed by humans, but affect health and environment importantly when a construction is made.

Additionally, a high percentage of research and applications focuses on the development of home automation technologies aimed to the control of devices inside the house, finding techniques that optimize the performance of the automation system that can, however, be escalated for the detection of certain particles determined in the bioconstruction technical norm, due to their use of temperature and humidity sensors.

In the same way, an environmentally friendly construction must tend to the use and adequate consumption of the available resources, that is why models have been proposed in order to detect the user's behaviors in function of factors such as time and temperature. This can become an adaptable model so that said behavior 
patterns are used in the rationalization of the house resources, inside and outside, generating an automated control and management, with continuous evaluation and analysis of the obtained data, in function of the available resources and consumption [29].

On the other hand, there are applications that are more common every day inside a home with the boom of loT, such as telehealth, smart home appliances and smart energy [30]. The level of complexity relies on the fact that measurement applications given to maintain the bioconstruction standards would have to compete against the current applications for the bandwidth of the house. Kua et al. (2017) propose the use of Active Queue Management (AQM) to provide optimization of the process flows, given that traditional FIFO (Firs In, First Out) algorithms are not functional for this type of loT models, where priority must be given to more relevant architecture processes. Another alternative is the one of Bera et al. (2017), who propose a software-defined networks model (SDN), which is economically better, besides being trustable given their configuration nature, which allows massive connections inside the network.

Taking into consideration the solutions based on the technologies above, it is ratified that IoT has the capacity to transform a residential construction into a smart home, adapting the input of Zafari, Papapanagiotou, \& Christidis (2016), that portrays the components that are part of a smart building, in order to make them part of a smart house as well (Figure 6). 


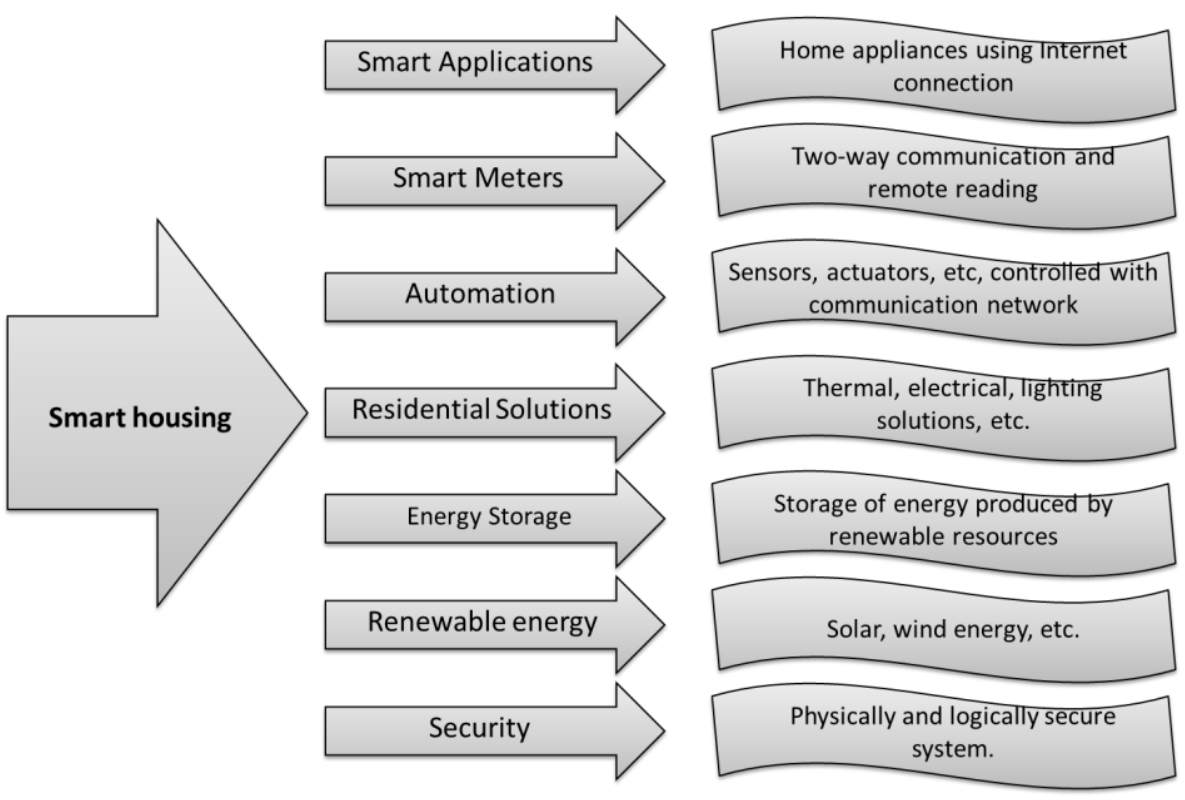

Fig. 6. Components of a smart construction. Adapted from [32].

\section{IoT Perspective on Bioconstructions}

Having as a base the research made, Table 2 shows a scenario of several technologies and tools that support the areas that make up an loT architecture.

Table 2. Integration of the proposed components for an loT implementation.

\begin{tabular}{|l|c|c|c|}
\hline \multicolumn{1}{|c|}{ IOT Component } & \multicolumn{3}{c|}{ Component Proposed for the Model } \\
\hline Energetic Consumption of the Devices & IEEE802.15.4 Standard & TensorFlow & TR \\
\hline Integration of Heterogeneous Devices & Middleware & TR \\
\hline Network Security & IEEE802.15.4 Standard & TR \\
\hline Information Transmission & AQM & SDN \\
\hline
\end{tabular}

In the same way, it is seen that the micro location project of Zafari et al. (2016) can be escalated to identify, through tracking, the exact location inside a construction of the measurable elements that are found in the three categories of the technical norm of Baubiologie.

It is important to highlight that the loT implementations carried out in a bioconstruction have a quantifiable analysis within, represented in energy saving through the use of resources. For this reason, in the scheme presented by Masera et al. (2011), the environmental resources of a biohouse were used, minimizing the energy consumption in a measurable way. This through tools such as TRNSYS for 
the estimation of energetic consumption, and ECOTECT for the lighting analysis, as part of the supports for the consolidation of loT indicators with bioconstructions.

\section{CONCLUSIONS}

The development and implementation of $5 \mathrm{G}$ allows to overcome some of the drawbacks that were present in loT, related with interoperability, security, energetic consumption and data transmission speed; contributing with a higher system optimization level, transparent at management and control levels.

In the bioconstruction area, there is a clearly defined norm that punctually characterizes the measurable elements inside the fields that must be taken into consideration in a construction. Table 3 presents a synthesis of the actual components that will allow the development of a bioconstruction through loT.

Table 3. IoT Elements and Tools vs Bioconstruction.

\begin{tabular}{|c|c|c|}
\hline $\begin{array}{l}\text { Bioconstruction } \\
\text { Elements }\end{array}$ & IoT Elements & Measuring Tools \\
\hline $\begin{array}{ll}\text { - IBN SBM-2015 } \\
\text { Norms } \\
\text { - Environmental and } \\
\text { Sustainable } \\
\text { Designs }\end{array}$ & 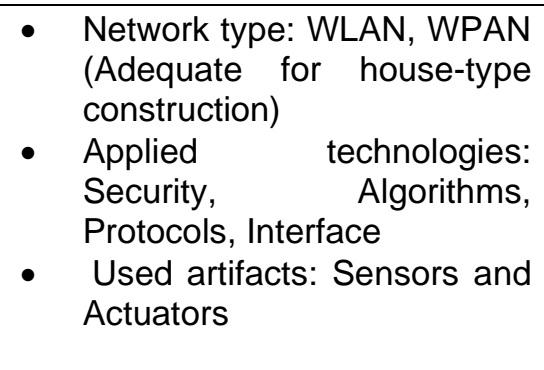 & 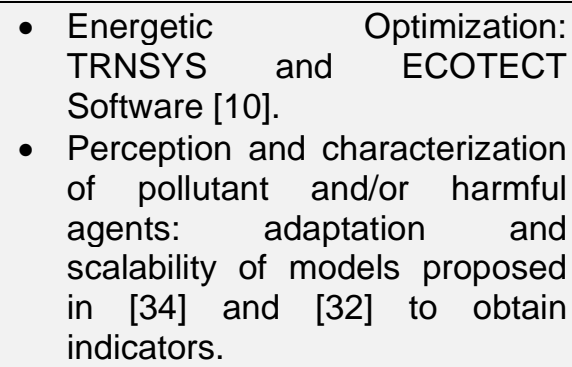 \\
\hline
\end{tabular}

There are investigations that aim to the development and optimization of environmental resources and renewable energies. It is clear that a bioconstruction, besides considering a sustainable and environmentally friendly design, also relates factors that protect the integrity of the people that inhabit it; it is in this field where the research level is non-existent. However, several existent applications can be adopted and escalated to be taken to an exact measurement, control and management of a smart house that fulfills the specifications of a bioconstruction. Even when the Baubiologie norm [2] is clear regarding the measurable fields that must be considered, nowadays there is no norm that aims to present a clear indicator of the use of available natural resources in a construction area, which is 
an interesting space that links normative resolution and technological supplying. We are talking about a qualitative exploitation, obviating the quantitative aspect, giving place to the absence of a clear normative that rules the efficiency in the use of available resources around the house, and that fulfills ponderation levels demanded by a bioconstruction.

The accelerated development of loT allows to create, through some of its most essential elements such as actuators and sensors, technological systems, either simple or complex, in an effective way. However, in a bioconstruction scope, there is the "economical" factor that must be considered with anticipation. While an loT system for natural resources exploitation allows a return of investment in a certain time, the investment in micro perception elements, actuators and sensors dedicated to the measurement of the valid technical norm, does not present a precise return, since its implementation aims for a health quality improvement service inside the house.

It is remarkable that people still focus on the functional aspect of loT implementations more than on intangible aspects guided by healthy conditions; therefore, the development of solutions focused on the monitoring and control of elements such as radiations, toxins and allergens is desirable for restricted industrial-like environments, but less common in residential spaces. Nevertheless, it is necessary for the users of bioconstructions to generate more conscience regarding said implications, as well as for the environmental and sustainable philosophy to have more granular parameters when discussing the habitability of spaces.

\section{AUTHOR'S CONTRIBUTION}

Fabián-Ricardo Corredor-Sánchez: Investigation, Writing - original draft.

Juan-Sebastián González-Sanabria: Methodology, Validation, Writing - review \& editing.

Miguel-Ángel Mendoza-Moreno: Validation, Writing - review \& editing. 


\section{REFERENCES}

[1] H. G. Cortés Mura, J. I. Peña Reyes, "De la sostenibilidad a la sustentabilidad. Modelo de desarrollo sustentable para su implementación en políticas y proyectos," Revista Escuela de Administración de Negocio, no. 78, pp. 40-54, 2015. https://doi.org/10.21158/01208160.n78.2015.1189

[2] Institut für Baubiologie + Nachhaltigkeit, Norma técnica de medición en baubiologie-SBM2015, 2015.

[3] G. Bedi, G. S. Member, G. K. Venayagamoorthy, S. Member, R. Singh, R. Brooks, S. Member, K. Wang, "Review of Internet of Things ( IoT ) in Electric Power and Energy Systems," IEEE Internet of Things Journal, vol. 5, no. 2, pp. 847-870, Apr. 2018. https://doi.org/10.1109/JIOT.2018.2802704

[4] M. Silverio-Fernández, S. Renukappa, S. Suresh, "What is a smart device? a conceptualisation within the paradigm of the internet of things," Visualization in Engineering, vol. 6, e3, 2018. https://doi.org/10.1186/s40327-018-0063-8

[5] O. Jo, Y. K. Kim, J. Kim, "Internet of Things for Smart Railway: Feasibility and Applications," IEEE Internet of Things Journal, vol. 5, no. 2, pp. 482-490, Apr. 2018. https://doi.org/10.1109/JIOT.2017.2749401

[6] G. A. Akpakwu, S. Member, A. M. Abu-mahfouz, S. Member, "A Survey on $5 \mathrm{G}$ Networks for the Internet of Things: Communication Technologies and Challenges," IEEE Access, vol. 6, pp. 3619-3647, 2018. https://doi.org/10.1109/ACCESS.2017.2779844

[7] Ecohabutar, "Qué es la bioconstrucción? Pautas y Materiales," 2019. http://www.ecohabitar.org/que-esla-bioconstruccion-pautas-y-materiales/

[8] Institut für Baubiologie + Nachhaltigkeit, Norma técnica de medición en baubiologie-SBM2008, 2008.

[9] A. Montesinos López, "El discurso de la bioconstrucción arquitectónica: divulgación y legitimación en revistas profesionales," Cultura, lenguaje y representación: revista de estudios culturales de la Universitat Jaume I, vol. 13, pp. 201-220, 2014. https://doi.org/10.6035/clr.2014.13.11

[10] Institut für Baubiologie + Nachhaltigkeit, Valores indicativos en Baubiologie para las zonas de descanso, 2015.

[11] Institut für Baubiologie + Nachhaltigkeit, Condiciones marco para mediciones técnicas. Aclaraciones y Complementos, 2015.

[12] N. L. Arango Ortiz, "Lineas guia de la bioconstruccion," Master Thesis, Università degli Studi di Ferrara, Italy, 2007.

[13] C. González-Amarillo, C. Cárdenas-García, M. Mendoza-Moreno, "M2M system for efficient water consumption in sanitary services, based on intelligent environment," DYNA, vol. 85, no. 204, pp. 311318, 2018. https://doi.org/10.15446/dyna.v85n204.68264

[14] C. González-Amarillo, C. Cárdenas-García, J. Caicedo-Muñoz, M. Mendoza-Moreno, "Smart Lumini: A Smart Lighting System for Academic Environments Using IOT-Based Open-Source Hardware", Revista Facultad de Ingeniería, vol. 29, no. 54, e11060, Jun. 2020. https://doi.org/10.19053/01211129.v29.n54.2020.11060

[15] C. A. González-Amarillo, J. C. Corrales-Muñoz, M. Á. Mendoza-Moreno, A. M. González-Amarillo, A. F. Hussein, N. Arunkumar, G. Ramirez-González, "An loT-Based Traceability System for Greenhouse Seedling Crops," IEEE, Access, vol. 6, pp. 67528-67535, 2018. https://doi.org/10.1109/access.2018.2877293

[16] L. Fidelity, "IoT Connectivity Technologies and Applications: A Survey," IEEE Access, vol. 8, pp. 67646-

Revista Facultad de Ingeniería (Rev. Fac. Ing.) Vol. 30 (55), e12266. January-March 2021. Tunja-Boyacá, Colombia. L-ISSN: 0121-1129, e-ISSN: 2357-5328, DOI: https://doi.org/10.19053/01211129.v30.n55.2021.12266 
Fabián-Ricardo Corredor-Sánchez; Juan-Sebastián González-Sanabria; Miguel-Ángel Mendoza-Moreno

67673, 2020. https://doi.org/10.1109/access.2020.2985932

[17] E. Fitzgerald, M. Pioro, A. Tomaszewski, "Energy-Optimal Data Aggregation and Dissemination for the Internet of Things," IEEE Internet of Things Journal, vol. 5, no. 2, pp. 955-969, Apr. 2018. https://doi.org/10.1109/JIOT.2018.2803792

[18] Y. Chen, F. Han, Y. H. Yang, H. Ma, Y. Han, C. Jiang, H. Q. Lai, D. Claffey, Z. Safar, K. J. R. Liu, "Timereversal wireless paradigm for green internet of things: An overview," IEEE Internet of Things Journal, vol. 1, no. 1, pp. 81-98, 2014. https://doi.org/10.1109/jiot.2014.2308838

[19] Z. A. Khan, "Using energy-efficient trust management to protect loT networks for smart cities," Sustainable Cities and Society, vol. 40, pp. 1-15, Jul. 2018. https://doi.org/10.1016/j.scs.2018.03.026

[20] G. B. Asencio, J. M. Maestre, J. M. Escaño, C. Martín Macareno, M. A. Molina, E. F. Camacho, "Interoperabilidad en sistemas domoticos mediante pasarela Infrarrojos-Zigbee," Revista Iberoamericana de Automática e Informática Industrial, vol. 8, no. 4, pp. 397-404, 2011. https://doi.org/10.1016/j.riai.2011.09.002

[21] M. R. Alam, M. B. I. Reaz, M. A. M. Ali, "A review of smart homes - Past, present, and future," IEEE Transactions on Systems, Man, and Cybernetics, Part C (Applications and Reviews), vol. 42, no. 6, pp. 1190-1203, Nov. 2012. https://doi.org/10.1109/TSMCC.2012.2189204

[22] M. A. A. da Cruz, J. J. P. C. Rodrigues, J. Al-Muhtadi, V. Korotaev, V. H. C. Albuquerque, "A Reference Model for Internet of Things Middleware," IEEE Internet of Things Journal, vol. 5, no. 2, pp. 871-883, Apr. 2018. https://doi.org/10.1109/JIOT.2018.2796561

[23] K. Zaheer, M. Othman, M. H. Rehmani, T. Perumal, "A Survey of Decision-Theoretic Models for Cognitive Internet of Things (CloT)," IEEE Access, vol. 18, no. 8, pp. 1-23, 2018. https://doi.org/10.1109/access.2018.2825282

[24] H. Jo, Y. I. Yoon, "Intelligent smart home energy efficiency model using artificial TensorFlow engine," Human-centric Computing and Information Sciences, vol. 8, e9, 2018. https://doi.org/10.1186/s13673018-0132-y

[25] K. Shafique, B. A. Khawaja, F. Sabir, S. Qazi, M. Mustaqim, "Internet of Things (IoT) for Next-Generation Smart Systems: A Review of Current Challenges, Future Trends and Prospects for Emerging 5G-loT Scenarios," IEEE Access, vol. 8, pp. 23022-23040, 2020. https://doi.org/10.1109/ACCESS.2020.2970118

[26] E.-R. Adolfo, R.-I. Erica, G.-B. Armando, L.-C. J. Antonio, C.-G. Joaquín, R.-I. Joel, "Plataforma autoconfigurable de monitoreo remoto para aplicaciones móviles en WSAN," Ingeniería, Investigación y Tecnología, vol. 16, no. 3, pp. 369-382, 2015. https://doi.org/10.1016/j.riit.2015.05.009

[27] M. C. Rodríguez-Sanchez, J. A. Hernández-Tamames, S. Borromeo, "Wireless System for Home appliances," Revista Iberoamericana de Tecnolgías del Aprendizaje, vol. 4, no. 1, pp. 75-82, 2009.

[28] A. M. Kurien, "The Narrowband Internet of Things (NB-loT) Resources Management Performance State of Art , Challenges, and Opportunities," IEEE Access, vol. 8, pp. 97658-97675, 2020. https://doi.org/10.1109/ACCESS.2020.2995938

[29] T. Kim, S. Bae, "Design of Smart Home Implementation Within loT Natural Language Interface," IEEE Access, vol. 8, pp. 84929-84949, 2020. https://doi.org/10.1109/access.2020.2992512

[30] M. Yamauchi, G. S. Member, Y. Ohsita, "Anomaly Detection in Smart Home Operation From User Behaviors and Home Conditions," in IEEE International Conference on Consumer Electronics, 2019, pp. 1-6. https://doi.org/10.1109/ICCE.2019.8661976

[31] J. Kua, S. H. Nguyen, G. Armitage, P. Branch, "Using Active Queue Management to Assist IoT

Revista Facultad de Ingeniería (Rev. Fac. Ing.) Vol. 30 (55), e12266. January-March 2021. Tunja-Boyacá, Colombia. L-ISSN: 0121-1129, e-ISSN: 2357-5328, DOI: https://doi.org/10.19053/01211129.v30.n55.2021.12266 
Internet of Things at the Service of Bioconstruction

Application Flows in Home Broadband Networks," IEEE Internet of Things Journal, vol. 4, no. 5, pp. 13991407, 2017. https://doi.org/10.1109/jiot.2017.2722683

[32] S. Bera, S. Misra, A. V. Vasilakos, "Software-Defined Networking for Internet of Things: A Survey," IEEE Internet of Things Journal, vol. 4, no. 6, pp. 1994-2008, 2017. https://doi.org/10.1109/iiot.2017.2746186

[33] F. Zafari, I. Papapanagiotou, K. Christidis, "Microlocation for internet-of-things-equipped smart buildings," IEEE Internet of Things Journal, vol. 3, no. 1, pp. 96-112, 2016. https://doi.org/10.1109/jiot.2015.2442956

[34] G. Masera, M. Grecchii, L. E. Malighetti, M. M. Sesana, D. Palazzoii, "Multidisciplinary design process: Urban, architectural and technological analyses for energy-efficient residential buildings in northern italy," International Journal for Housing Science and Its Applications, vol. 35, no. 1, pp. 11-21, 2011.

Revista Facultad de Ingeniería (Rev. Fac. Ing.) Vol. 30 (55), e12266. January-March 2021. Tunja-Boyacá, Colombia. L-ISSN: 0121-1129, e-ISSN: 2357-5328, DOI:

https://doi.org/10.19053/01211129.v30.n55.2021.12266 